\title{
Islamic Banking-A Cross Cultural Patronage Study among the Students in Chennai
}

\author{
Yaaseen Masvood $^{1} \&$ Y. Lokeswara Choudary ${ }^{2}$ \\ ${ }^{1}$ School of Management, SRM University, Chennai, India \\ ${ }^{2}$ Dept. of Commerce, Government Arts College, Chennai, India \\ Correspondence: Yaaseen Masvood, School of Management, SRM University, Chennai-603203, Tamil Nadu, \\ India. Tel: 91-098-4127-3839. E-mail: masvood@gmail.com
}

Received: October 30, 2014 Accepted: December 19, 2014 Online Published: January 14, 2015

doi:10.5539/ass.v11n4p310 URL: http://dx.doi.org/10.5539/ass.v11n4p310

\begin{abstract}
Islamic Banking is any banking activity performed on the basis of Islamic laws of jurisprudence. The two fundamental sources of Islamic law are the Quran, (which is the Holy Book of Muslims) and the Sunnah, (which are the Traditions of the final Prophet Muhammad (Peace Be upon Him)). Islamic methods of finance revolve around a few basic concepts, the most important of which is the prohibition of 'Riba' or interest. Although this concept is relatively new in the Indian context, the Islamic financial world is now a global force to reckon with and India might miss out if the opportunity is not capitalized. It is worth mentioning that the total value of Islamic business stands at $\$ 6.7$ trillion and is growing at a rate of $16-20 \%$ a year. Also, the fact that many non-Muslim countries like UK have opened full-fledged Islamic banks point to the fact that Islamic finance or Islamic banking is not limited to Muslims alone. Therefore, India's ambitions of becoming an Asian financial hub cannot be met without capitalizing into the pool of Islamic Finance. The purpose of this paper is to study the level of awareness of students of private universities in Chennai and to study the cross cultural patronage factors towards Islamic Banking. The findings reveal that the respondents have a positive and favorable patronage towards Islamic Banking due to their perception about its success in other parts of the world.
\end{abstract}

Keywords: Islamic Banking, Islamic finance, patronage, interest-free banking, patronage across cultures

\section{Introduction}

\subsection{Background}

Islamic Banking is any banking activity in a financial institution which operates on the basis of and conforms to the principles of Islamic law (Shariah). Hence, Islamic Banking, which is a part of Islamic Economics, is centered on the principle of the prohibition of interest. In addition to this no-interest rule, it also revolves around certain other principles-the prohibition of high risk ventures, gambling, speculative transactions and dealing in certain forbidden commodities (like pork, alcohol, arms and ammunition), and investing only in a social responsible way. The Islamic methods of finance are therefore socio-economic in nature, as it not only takes care of making profits but also addresses social responsibility. Since these aspects are equally applicable for Muslims and non-Muslims, it becomes clear that Islamic banking, and therefore its benefits, are not restricted to Muslims alone but are applicable to the whole of the humanity in general. This is why many a non-Muslim country like US, UK, France and Malaysia have shown keen interest in adopting Islamic Methods of finance. India nurtures the ambition of becoming an Asian financial hub. This ambition cannot materialize if it cannot tap the pool of Islamic Finance. Therefore, this study which is aimed assessing the patronage levels towards Islamic banking among the students of private universities assumes significance.

\subsection{Definition of Islamic Finance}

Islamic Finance is any finance activity which is carried out within the stipulated principles of Islamic law. The two basic and fundamental sources of Islamic law are the Quran, the holy Book of Muslims and the Sunnah, the Traditions of Prophet Muhammad (Peace and Blessings of Allah be upon Him). In Islam, money is not recognized as a subject-matter of trade, except in some special cases. Money has no intrinsic utility; it is only a medium of exchange. Therefore, there is no room for making profits through the exchange of these units, inter se. Profit is generated when something having intrinsic utility is sold for money or when different currencies are 
exchanged, one for another. The profit earned through dealing in money of the same currency or the papers representing them is interest and hence prohibited. Therefore, unlike conventional finance, Islamic finance is always based on illiquid assets which create real assets and inventories. (Usmani M.T, An Introduction to Islamic Finance, Idara Publications, 2008).

\subsection{Relevance of Islamic Banking to the Indian Context}

Although Islamic banking has got a religious connotation, it is a myth that must be dispelled. It is not in any respect restricted to the Muslim community alone. This is why in countries like Malaysia and UK, where Islamic banks are operational over the last few decades, two out of every five retail customers are non-Muslims. Also there are many countries, like France, Germany and Malaysia, in which Muslims are not a majority, where Islamic banks have been introduced or at least there exists an Islamic banking window in a conventional bank. This is not only because it acts as a tool for financial inclusion but also because it makes business sense, as its principles prohibit highly risky financial products like derivative contracts, which was the root-cause of the recent sub-prime crisis. India would do well to capitalize on the Islamic financial world and attract a lot of foreign remittances especially from GCC countries.

According to a report of Reserve Bank of India, a whopping US \$1.5trillion as interests accrued on deposits of Muslims are lying unclaimed in different banks in India. This is because an overwhelming majority of Muslims do not want to avail of it, due to the strong religious implications. Such a huge sum of money is lying idle and is not ploughed back into the economy of the country. Therefore, the Finance ministry and Reserve Bank of India need to re-examine the stand on Islamic finance and create a conducive environment for the Indian Muslim populace to contribute to the growth of this great country.

\section{Review of Literature}

Although the concept and practice of Islamic Finance has been in vogue as early as the time of Prophet Muhammad (PBUH), the first formal Islamic banking transaction was conducted in Mit Ghamr in Egypt as late as in 1963 only. Islamic Banking is a banking activity carried out based on the principles laid out in Shariah i.e. the laws of Islamic jurisprudence. Since Muslims cannot receive or pay interest, they are unable to conduct business with conventional banks. (Gerrard \& Cunningham, 1997).

Globally there have been studies carried out in this field and the earliest studies were carried out by Erol and El-Bdour in 1989. Gait and Worthington (2009) investigated the attitudes, perception and motivation towards IF among 385 Libyan retail customers using factor analysis and discriminant analysis. They both found that most respondents were potential users of Islamic finance at the retail level and concluded that religion and community service are the most important factors determining the same.

Muhammad ZMamun (2011) investigated 100 responses each from 11 Islamic banks and 13 banks which offer dual-both Islamic and Conventional banking-system in Bangladesh to study prospects and problems of Islamic banking and found that the foremost factor making Islamic banking attractive to customers is the adherence to the rules of Shariah.

Perception towards Islamic banking among 134 respondents of the people of Gambia LGA by Fada and Bundi Wabekwa (2012) revealed that Islamic banking is popular among young and educated people and majority of the respondents have heard of Islamic Banking.

In an exploratory research among 103 expatriate workers in Saudi Arabia of whom majority were Indians, the Perception of non-Muslims towards Islamic banking, was studied by Sultan Emir Hidayat and Nouf K Al Baward (2012), it was found that a majority of non-Muslim customers perceive Islamic banking as diverse and suitable in satisfying their banking needs.

Dineshwar Ramdhony (2013) investigated the awareness about Islamic Banking terms and preference for investment among 232 Muslims and non-Muslims from Mauritius and found that more than half of the respondents have heard about the terms and concluded that Islamic banks cannot target Muslims alone to prosper.

A lot of studies have been carried out among the Malaysians. Mark Loo (2010) studied the differences in attitude and perception towards Islamic banking between Muslims and non-Muslims by taking a sample of 200 Malaysians-100 Muslims and 100 non-Muslims in Klang valley of Malaysia and found that Muslims are supportive of Islamic banking while non-Muslims view Islamic banking as relevant primarily to Muslims.

Ahsanul Haque (2010) conducted a face to face interview of 473 Malaysian customers to study the attitudinal difference of Malaysian customers about Islamic banking and found Malaysian consumers have positive attitude 
towards Islamic banking and a significant attitudinal difference exists only between Malay \& Chinese and between Chinese \& Indian, while the overall attitudes of all three races were positive towards Islamic banking.

Norafifah Ahmad and Sudin Haron (2011) studied customer perception of Islamic banking products and services among 45 corporate respondents from Kuala Lumpur and concluded that Islamic banking system had good potential as an alternative to the conventional system. Abdul Aziz Abdullah, et al., (2012) studied the perception of non-Muslims towards Islamic banks among 152 customers of Kuwait Finance House, Kuala Lumpur, Malaysia and concluded that Islamic banking services are making headway among non-Muslims. Norma Md. Saad (2012) compared the customer satisfaction of Islamic and Conventional Banks in Malaysia and also investigated the relationship between different demographic variables and the satisfaction of customers. A large sample of 1153 respondents used in this study revealed that the customer satisfaction of a particular bank often depends on the quality of services offered.

In Turkey, H. Saduman Okumus and Elif Generen Genc (2013) did a random sampling of 281 customers of banks in Turkey to study Customers' awareness and bank selection criteria and found that most of the respondents give the highest importance to religious beliefs as a major factor for selection of bank. Ramana Sheikh and Mohammad Faisal Ahammad (2013) studied the feasibility of establishing Islamic Banks in UK by obtaining responses from both Muslims and non-Muslims and found that there is a lack of awareness and understanding of the alternative banking system. Hence, it was suggested that Islamic banks in UK undertake more aggressive marketing and promotion of its services in order to increase awareness among potential customers.

In the Indian context, a few studies have been done in this regard. A study by Urvi Amin (2012) using a non-probability sampling of 100 respondents from the district of Ahmedabad, Gujarat showed that Gujarati Muslims are not inclined towards following the principles of Shariah while investing. Yet they showed interest in Islamic financial products, if made available to them. Nissar Ahmed Yatoo and S. Sudalai Muthu (2013) analysed the demographic variables on attitude towards Islamic Banking by carrying out an empirical study based on primary data collected from 6 states in India and found that despite global success, Muslims in India are not aware of the facts, issues and practices of Islamic banking and finance. In a similar study carried out by Md. Faisal, Asif Akhtar and Asad Rahman, across four class B cities of North India, they found that both Muslims and non-Muslims showed a positive attitude towards Islamic banking. Nissar Ahmed Yatoo and S. Sudalai Muthu (2013), in another research, studied the impact of demographic variables on the opinion about the nature and purpose of Islamic methods of finance among 609Indians and found that Muslims in India connote religious value rather than commercial value to Islamic finance. Sajeevan Rao and Sharma (2010) conducted an empirical analysis to find out the bank selection criteria among 312 MBA students in Delhi and concluded that reliability is an important choice criterion. Yet another study carried out by Shanmugam Muniswamy, et al., (2013), among 150 teachers from 10 colleges in Chennai city, revealed that significant difference exists between Muslims and non-Muslims in their willingness to accept Islamic finance.

\section{Research Methodology}

\subsection{Procedure}

For the purpose of this study, three reputed private universities in Chennai were selected. These three Universities were SRM University, B. S. Abdur Rahman University and Sathyabama University. The students admitted in these institutions of higher education are in the faculty of (i) Engineering \& Technology, (ii) Science and Humanities, (iii) Medical and Paramedical and (iv) Management. The reason why these Universities were chosen is because these three private universities attract student population not only from different states in the country but also from abroad from countries like Nigeria, Afghanistan, Somalia, Egypt, Eriteria etc. Majority of the students have bank accounts and are aware of the basic aspects of finance and the risks associated with it. The students were selected from all these different faculty of study depending on the convenience of the researcher.

\subsection{Sample}

A pilot study was initially conducted to test the validity of the questionnaire. After determining the sample size based on the pilot study, the sample size was fixed at 280. Therefore, 350 questionnaires were sent out. Out of this, 150 responses were received. On scrutiny of the sample, incomplete and dual entry questionnaires were removed and for the analysis, 140 questionnaires were considered suitable for analysis and discussion.

\subsection{Instrument}

The data required for the study is collected through a structured questionnaire which was tested through pilot 
study and a reliability test. A modified version of the questionnaire was used for the final study. The reliability (Cronbach's) alpha is found at 0.786 and therefore considered reliable.

\subsection{Research Gap}

From the review of literature, it becomes clear that there has been no study conducted in the Indian context with specific reference to the student community. The student community is chosen as respondents because they are the future of the nation and would be involved in financial decision making process once they are employed. Therefore, this study assumes significance.

\subsection{Analysis}

The following objectives were framed in order to undertake the study.

1) To understand the level of awareness about Islamic banking among the students in selected private universities in Chennai.

2) To analyze the factors (i.e. nationality, faculty and university of study) affecting the patronage towards Islamic banks in India.

With the above objectives in mind, the following three hypotheses were framed.

a) $\mathrm{H}_{01}$ : There is no significant difference between the perceptions of Indian and foreign students and their patronage towards Islamic banking in India.

b) $\mathrm{H}_{02}$ : There is no significant relationship between the perception of the students of different faculty of study and the patronage towards Islamic banking in India.

c) $\mathrm{H}_{03}$ : There is no significant relationship between the perception of the students of different universities and their patronage of Islamic banking in India.

\subsection{Tools Used}

In order to carry out the above study, percentage analysis, t- test and ANOVA were used. The above tests were carried out using SPSS version 20.

\section{Data Analysis and Discussion}

\subsection{Profile of the Respondents}

Table 1. Distribution of sample on the basis of key demographical variables

\begin{tabular}{llllll}
\hline Description & N & $\mathbf{\%}$ & Description & N & \% \\
\hline University of study: & & & Religion: & & \\
SRM & $\mathbf{7 9}$ & 56.4 & Hindu & 46 & 32.9 \\
BSA & 48 & 34.3 & Muslim & $\mathbf{6 7}$ & 47.9 \\
Sathyabama & 13 & 9.3 & Christian & 27 & 19.3 \\
Total & 140 & 100.0 & Total & 140 & 100.0 \\
Gender: & & & Basic awareness status: & & \\
Male & 119 & 85.0 & Aware & $\mathbf{7 9}$ & 56.4 \\
Female & 21 & 15.0 & Not Aware & 61 & 43.6 \\
Total & 140 & 100.0 & Total & 140 & 100.0 \\
Faculty of study: & & & Reasons to prefer Islamic banks: & & \\
Engineering & & & & & \\
\&Technology & $\mathbf{7 2}$ & 51.4 & Religious Reason & 37.9 \\
Science and Humanities & 3 & 2.1 & Socially Responsible investing & 11 & 7.9 \\
Medical & 11 & 7.9 & Success story in the rest of the world & $\mathbf{3 9}$ & 27.9 \\
Management & $\mathbf{5 4}$ & 38.6 & Sustainability of profit-loss sharing model & 6 & 4.3 \\
Total & 140 & 100.0 & Recommendation from family/friends & 9 & 6.4 \\
Nationality & & & Attractiveness of the various financial Products & 12 & 8.6 \\
Indian & & & services & 6 & 7.2 \\
Foreign & 116 & 82.9 & Immediate Vicinity & 4 & 2.9 \\
Total & 24 & 17.1 & Other reasons & 140 & 100.0 \\
\hline
\end{tabular}


It is observed from Table 1 that $85 \%$ of the respondents were male while the rest were female. Most of the respondents $(51.4 \%)$ were from the faculty of Engineering and Technology and a significant part $(38.6 \%)$ were from the Faculty of Management. While $82.9 \%$ of them were from India, the rest are other nationals. Respondents from SRM University formed 56.4\% while those from B. S. Abdur Rahman University were 34.3\% and those from Sathyabama University constituted 9.3\%. More than half of the respondents (56.4\%) are aware of the concept of Islamic banking. and the reasons why they would prefer Islamic banking is not only because of religiosity but also because of the success of Islamic banks in the rest of the world. This assumes significance for the study because more than half of the respondents (52.2\%) are not Muslims. i.e. Hindus and Christians. This concurs well with the findings of Ahsanul Haque (2010).

\subsection{Descriptive Statistics}

Table 2. Perceptions on future prospects of Islamic Banking in India

\begin{tabular}{lll}
\hline Future prospects of Islamic banks & Frequency & Percentage \\
\hline Very Strong & 35 & 25.0 \\
Strong & 48 & 34.3 \\
Average & 48 & 34.3 \\
Weak & 6 & 4.3 \\
Very Weak & 3 & 2.1 \\
Total & $\mathbf{1 4 0}$ & $\mathbf{1 0 0 . 0}$ \\
\hline
\end{tabular}

Table 3. Differences between the perceptions of Indian and foreign students and their patronage towards Islamic banks

\begin{tabular}{|c|c|c|c|c|c|c|}
\hline Variables for study & Nationality & $\mathbf{N}$ & Mean & SD & t- value & p-value \\
\hline \multirow{2}{*}{ Awareness } & Indian & 116 & 22.95 & 4.257 & \multirow{2}{*}{1.543} & \multirow{2}{*}{0.125} \\
\hline & Foreign & 24 & 24.50 & 5.477 & & \\
\hline \multirow{2}{*}{ Religious Reasons } & Indian & 116 & 8.81 & 3.059 & \multirow{2}{*}{0.323} & \multirow{2}{*}{0.747} \\
\hline & Foreign & 24 & 8.58 & 3.501 & & \\
\hline \multirow{2}{*}{ Products and Services } & Indian & 116 & 9.57 & 2.993 & \multirow{2}{*}{0.160} & \multirow{2}{*}{0.873} \\
\hline & Foreign & 24 & 9.46 & 3.464 & & \\
\hline \multirow{2}{*}{ Vicinity/Ease of Access } & Indian & 116 & 8.54 & 3.005 & \multirow{2}{*}{0.840} & \multirow{2}{*}{0.402} \\
\hline & Foreign & 24 & 7.96 & 3.557 & & \\
\hline \multirow{2}{*}{ Attractiveness } & Indian & 116 & 7.77 & 2.941 & \multirow{2}{*}{0.553} & \multirow{2}{*}{0.581} \\
\hline & Foreign & 24 & 8.13 & 2.593 & & \\
\hline \multirow{2}{*}{ Reputation } & Indian & 116 & 9.56 & 2.780 & \multirow{2}{*}{2.535} & \multirow{2}{*}{$.012 \% *$} \\
\hline & Foreign & 24 & 11.17 & 3.046 & & \\
\hline \multirow{2}{*}{ Cost/Benefit } & Indian & 116 & 9.38 & 2.383 & \multirow{2}{*}{1.823} & \multirow{2}{*}{0.071} \\
\hline & Foreign & 24 & 10.38 & 2.683 & & \\
\hline \multirow{2}{*}{ Perception } & Indian & 116 & 16.66 & 4.956 & \multirow{2}{*}{2.671} & \multirow{2}{*}{$0.008^{* *}$} \\
\hline & Foreign & 24 & 19.54 & 4.064 & & \\
\hline \multirow{2}{*}{ Motivation } & Indian & 116 & 22.95 & 5.703 & \multirow{2}{*}{2.791} & \multirow{2}{*}{$0.007 * *$} \\
\hline & Foreign & 24 & 26.33 & 4.724 & & \\
\hline \multirow{2}{*}{ Bottlenecks for Implementation } & Indian & 116 & 16.41 & 3.919 & \multirow{2}{*}{0.063} & \multirow{2}{*}{0.950} \\
\hline & Foreign & 24 & 16.46 & 2.963 & & \\
\hline \multirow{2}{*}{ Suggestions for Implementation } & Indian & 116 & 13.98 & 4.226 & \multirow{2}{*}{2.771} & \multirow{2}{*}{$0.006 * *$} \\
\hline & Foreign & 24 & 16.50 & 3.022 & & \\
\hline Overall Patronage towards Islamic Banking & Indian & 116 & 146.57 & 27.203 & 2.120 & 0.036* \\
\hline & Foreign & 24 & 159.00 & 20.041 & & \\
\hline
\end{tabular}

It is observed from Table 2 that the respondents perceived that the future prospects of Islamic banking in India to be strong. This indicates that there is a need for the introduction of Islamic banks, at least in a phased manner. This presents a new opportunity to the banks and the customers. The results of this study are similar to the study 
of Beng Soon Chong and Ming-Hua Liu (2009) in Malaysia.

4.3 Differences between the Perceptions of Indian and Foreign Students and Their Patronage towards Islamic Banking in India

It is observed from Table 3 that the p value is less than 0.01 for the following variables, namely, reputation, perception, motivation, and overall patronage towards Islamic banking. Therefore, the null hypothesis is rejected at $1 \%$ level of significance for these variables. In other words, there is a highly significant difference between the Indian and foreign students with respect to the above variables.

The respondents from nationalities other than India exhibited a high level of motivation (with mean value 26.33) towards Islamic banking. This is because of the prior exposure of these respondents to Islamic banking practices in their countries.

4.4 Relationship between the Perceptions of Students of Different Faculty of Study and Their Patronage towards Islamic Banking in India

It is observed from Table 4 that the $\mathrm{p}$ value is less than 0.01 for the following variables, namely, awareness, religious reasons, ease of access, attractiveness, reputation and motivation. Hence, the null hypothesis is rejected at $1 \%$ level of significance. Stated differently, there is a highly significant relationship between the perceptions of students of different faculty of study and their patronage towards Islamic banks in India.

Table 4. Relationship between the perceptions of students of different faculty of study and their patronage towards Islamic banks in India

\begin{tabular}{|c|c|c|c|c|c|c|c|}
\hline \multirow{2}{*}{ Variables for study } & & \multicolumn{4}{|c|}{ Faculty of Study } & \multirow{2}{*}{$\begin{array}{l}\text { F } \\
\text { value }\end{array}$} & \multirow{2}{*}{$\begin{array}{l}\mathbf{p} \\
\text { value }\end{array}$} \\
\hline & & E\&T & S\&H & MED & MGMT & & \\
\hline Awareness & $\begin{array}{l}\text { Mean } \\
\text { SD }\end{array}$ & $\begin{array}{l}22.90 \\
(4.47)\end{array}$ & $\begin{array}{l}\mathbf{2 9 . 3 3} \\
(2.31)\end{array}$ & $\begin{array}{l}26.18 \\
(6.82)\end{array}$ & $\begin{array}{l}22.69 \\
(3.62)\end{array}$ & 4.048 & $.009 * *$ \\
\hline Religious Reasons & $\begin{array}{l}\text { Mean } \\
\text { SD }\end{array}$ & $\begin{array}{l}9.10 \\
(3.45)\end{array}$ & $\begin{array}{l}\mathbf{1 3 . 3 3} \\
(2.89)\end{array}$ & $\begin{array}{l}9.55 \\
(3.62)\end{array}$ & $\begin{array}{l}7.93 \\
(2.18)\end{array}$ & 4.203 & $.007 * *$ \\
\hline Products and Services & $\begin{array}{l}\text { Mean } \\
\text { SD }\end{array}$ & $\begin{array}{l}9.40 \\
(3.17)\end{array}$ & $\begin{array}{l}\mathbf{1 1 . 0 0} \\
(1.73)\end{array}$ & $\begin{array}{l}7.82 \\
(3.22)\end{array}$ & $\begin{array}{l}10.02 \\
(2.85)\end{array}$ & 1.906 & .132 \\
\hline Vicinity/Ease of Access & $\begin{array}{l}\text { Mean } \\
\text { SD }\end{array}$ & $\begin{array}{l}8.35 \\
(3.26)\end{array}$ & $\begin{array}{l}8.00 \\
(1.73)\end{array}$ & $\begin{array}{l}5.91 \\
(2.95)\end{array}$ & $\begin{array}{l}\mathbf{9 . 1 1} \\
(2.72)\end{array}$ & 3.507 & $.017 * *$ \\
\hline Attractiveness & $\begin{array}{l}\text { Mean } \\
\text { SD }\end{array}$ & $\begin{array}{l}7.82 \\
(3.12)\end{array}$ & $\begin{array}{l}7.00 \\
(1.73)\end{array}$ & $\begin{array}{l}5.36 \\
(1.57)\end{array}$ & $\begin{array}{l}\mathbf{8 . 3 9} \\
(2.54)\end{array}$ & 3.651 & $.014 * *$ \\
\hline Reputation & $\begin{array}{l}\text { Mean } \\
\text { SD }\end{array}$ & $\begin{array}{l}9.38 \\
(2.91)\end{array}$ & $\begin{array}{l}9.67 \\
(.58)\end{array}$ & $\begin{array}{l}8.45 \\
(2.84)\end{array}$ & $\begin{array}{l}\mathbf{1 0 . 7 4} \\
(2.71)\end{array}$ & 3.406 & $.020 * *$ \\
\hline Cost/Benefit & $\begin{array}{l}\text { Mean } \\
\text { SD }\end{array}$ & $\begin{array}{l}9.28 \\
(2.46)\end{array}$ & $\begin{array}{l}10.33 \\
(1.53)\end{array}$ & $\begin{array}{l}10.27 \\
(3.32)\end{array}$ & $\begin{array}{l}9.72 \\
(2.30)\end{array}$ & .799 & .497 \\
\hline Perception & $\begin{array}{l}\text { Mean } \\
\text { SD }\end{array}$ & $\begin{array}{l}16.89 \\
(5.55)\end{array}$ & $\begin{array}{l}\mathbf{2 1 . 0 0} \\
(5.29)\end{array}$ & $\begin{array}{l}20.27 \\
(4.80)\end{array}$ & $\begin{array}{l}16.65 \\
(3.70)\end{array}$ & 2.412 & .070 \\
\hline Motivation & $\begin{array}{l}\text { Mean } \\
\text { SD }\end{array}$ & $\begin{array}{l}23.56 \\
(6.04)\end{array}$ & $\begin{array}{l}27.33 \\
(5.51)\end{array}$ & $\begin{array}{l}\mathbf{2 8 . 2 7} \\
(5.41)\end{array}$ & $\begin{array}{l}22.31 \\
(4.69)\end{array}$ & 4.088 & $.008 * *$ \\
\hline Bottlenecks for Implementation & $\begin{array}{l}\text { Mean } \\
\text { SD }\end{array}$ & $\begin{array}{l}16.92 \\
(4.34)\end{array}$ & $\begin{array}{l}16.67 \\
(3.51)\end{array}$ & $\begin{array}{l}\mathbf{1 7 . 0 0} \\
(2.83)\end{array}$ & $\begin{array}{l}15.61 \\
(2.97)\end{array}$ & 1.351 & .260 \\
\hline Suggestions for Implementation & $\begin{array}{l}\text { Mean } \\
\text { SD }\end{array}$ & $\begin{array}{l}14.07 \\
(4.44)\end{array}$ & $\begin{array}{l}\mathbf{1 7 . 6 7} \\
(2.08)\end{array}$ & $\begin{array}{l}16.18 \\
(3.66)\end{array}$ & $\begin{array}{l}14.33 \\
(3.82)\end{array}$ & 1.469 & .226 \\
\hline $\begin{array}{l}\text { Overall Patronage towards Islamic } \\
\text { Banking }\end{array}$ & $\begin{array}{l}\text { Mean } \\
\text { SD }\end{array}$ & $\begin{array}{l}147.65 \\
(29.26)\end{array}$ & $\begin{array}{l}\mathbf{1 7 1 . 3 3} \\
(15.95)\end{array}$ & $\begin{array}{l}155.27 \\
(25.53)\end{array}$ & $\begin{array}{l}147.50 \\
(22.76)\end{array}$ & 1.032 & .380 \\
\hline
\end{tabular}

The respondents belonging to the Faculty of Science and Humanities have shown a high level of awareness (with mean value 29.33) while those of the Faculty of Management have placed a high level of importance for factors such as reputation of the bank, ease of access and Attractiveness of the bank (with mean values 10.74,9.11,8.39 
respectively). This may be because the respondents belonging to Faculty of Science and Humanities and Faculty of Management are better exposed to banking concepts, at least theoretically compared to their counterparts in Medicine and Engineering \& Technology.

4.5 Relationship between Perception of Students of Different Universities and the Patronage towards Islamic Banking in India

It is observed from Table. 5 that the $\mathrm{p}$ value is less than 0.05 for the following variables, namely, Awareness, Religious reasons, Products and Services and hence the null hypothesis is rejected at $5 \%$ level of significance for these variables. In other words, there is a significant relationship between the perception of students of different Universities and their patronage of Islamic banking in India with regard to these variables.

Table 5. Relationship between the perception of students of different universities and their patronage towards Islamic banks

\begin{tabular}{|c|c|c|c|c|c|c|}
\hline \multirow{2}{*}{ Variables for study } & & \multicolumn{3}{|c|}{ Private Universities } & \multirow{2}{*}{ F value } & \multirow{2}{*}{ P value } \\
\hline & & SRM & BSA & Sathyabama & & \\
\hline \multirow{2}{*}{ Awareness } & Mean & 22.37 & 24.42 & 23.92 & \multirow{2}{*}{3.379} & \multirow{2}{*}{$.037^{*}$} \\
\hline & SD & $(4.58)$ & $(4.71)$ & (1.04) & & \\
\hline \multirow{2}{*}{ Religious Reasons } & Mean & 8.10 & 9.75 & 9.23 & \multirow{2}{*}{4.525} & \multirow{2}{*}{$.013 *$} \\
\hline & $\mathrm{SD}$ & $(2.79)$ & $(3.76)$ & $(.44)$ & & \\
\hline \multirow{2}{*}{ Products and Services } & Mean & 9.57 & 8.98 & 11.54 & \multirow{2}{*}{3.707} & \multirow{2}{*}{$.027^{*}$} \\
\hline & SD & $(3.07)$ & $(3.25)$ & $(.97)$ & & \\
\hline \multirow{2}{*}{ Vicinity/Ease of Access } & Mean & 8.87 & 7.90 & 7.85 & \multirow{2}{*}{1.768} & \multirow{2}{*}{.174} \\
\hline & SD & $(2.85)$ & $(3.77)$ & $(.55)$ & & \\
\hline \multirow{2}{*}{ Attractiveness } & Mean & 7.96 & 7.94 & 6.62 & \multirow{2}{*}{1.279} & \multirow{2}{*}{.282} \\
\hline & SD & $(2.49)$ & $(3.68)$ & $(.96)$ & & \\
\hline \multirow{2}{*}{ Reputation } & Mean & 9.89 & 9.25 & 11.69 & \multirow{2}{*}{1.279} & \multirow{2}{*}{.282} \\
\hline & SD & $(2.84)$ & (3.13) & $(.63)$ & & \\
\hline \multirow{2}{*}{ Cost/Benefit } & Mean & 9.52 & 9.00 & 11.77 & \multirow{2}{*}{3.857} & \multirow{2}{*}{.023} \\
\hline & SD & $(2.43)$ & $(2.50)$ & $(.60)$ & & \\
\hline \multirow{2}{*}{ Perception } & Mean & 17.42 & 16.73 & 17.08 & \multirow{2}{*}{7.086} & \multirow{2}{*}{$.001 * *$} \\
\hline & SD & $(4.33)$ & $(6.34)$ & $(.86)$ & & \\
\hline \multirow{2}{*}{ Motivation } & Mean & 23.70 & 23.92 & 21.08 & \multirow{2}{*}{.291} & \multirow{2}{*}{.748} \\
\hline & SD & $(5.49)$ & $(6.59)$ & $(.28)$ & & \\
\hline \multirow{2}{*}{ Bottlenecks for Implementation } & Mean & 15.84 & 17.23 & 16.92 & \multirow{2}{*}{1.366} & 250 \\
\hline & SD & $(3.35)$ & $(4.69)$ & $(.28)$ & & 259 \\
\hline Surastions for Imnlomontotion & Mean & 14.29 & 14.10 & 16.31 & 1536 & 210 \\
\hline suggesurons ior mimpientintation & SD & $(3.79)$ & $(4.99)$ & (1.97) & 1.550 & .219 \\
\hline Overall Patronage towards Islamic Banking & Mean & 147.52 & 149.21 & 154.00 & 345 & 709 \\
\hline 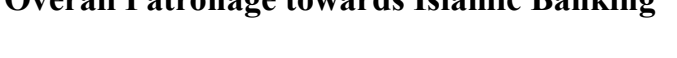 & SD & $(24.03)$ & $(33.21)$ & $(2.35)$ & 管 & (109 \\
\hline
\end{tabular}

The respondents belonging to B. S. Abdur Rahman University showed a higher level of awareness (with a mean value of 24.42). This is because it is a Muslim-run institution and it offers courses on Islamic finance to its post-graduate management students. 


\section{Conclusion}

\subsection{The Road Ahead}

This study has drawn its sample from the student community among the three private universities in Chennai. Therefore, in order to extend the findings of this study to the general populace would be inappropriate. However, the findings of this research gain significance on account of the fact that this sample represents an educated segment of the entire population and thus, act as a pre-cursor to a detailed study involving various other such demographic denominations. The future directions for this research could be carried out by drawing such clusters across the various demographic profiles of the Indian Population.

\subsection{Suggestions}

This study has revealed that Islamic banking has got a favorable patronage among the respondents. Although more than half of the respondents are non-Muslims, they perceive that the future of Islamic banking in India is bright, notwithstanding the regulatory and politico-social hurdles along the way of its implementation. As the Islamic banking will bring about the financial inclusion of the marginal sections of the society, it has to be implemented at least in a phased manner. This will not only help India attract foreign remittances especially from GCC countries but also to realize its dream of becoming a financial hub. Thus, this calls for an unbiased look into the various aspects of introducing Islamic financial services in India.

\section{References}

Abduh, M., \& Omar, M. A. (2012). Islamic-Bank selection criteria in Malaysia: An AHP Approach. Business Intelligence Journal, 5(2), 271-281.

Abdullah, A. A., Sidek, R., \& Adnan, A. A. (2012). Perception of non-Muslim Customers towards Islamic Banks in Malaysia. International Journal of Business and Social Science, 3(11), 151-163.

Adnan, A. A., Nasir, N. A. N., \& Yusof, D. M. (2013). Bank Choice behavior among Malaysian Muslims: A Qualitative Approach. International Research Journal of Social Sciences, 3(2), 1-8.

Amin, U. (2012). Islamic Banking in India: Religious and Socio-Economic Perspectives Affecting Muslim Investors of Ahmedabad District in Gujarat. International Journal of Research in Commerce, IT and Management, 2(1), 116-121.

Chebab, S., \& Zribi, H. (2012). Expected regret and Islamic banking in emerging countries: The case of Tunisia. Journal of Business Studies Quarterly, 3(4), 119-131.

Erol, C., \& El-Bdour, R. (1989). Attitudes, Behaviour and Patronage Factors of Bank customers towards Islamic Banks. International Journal of Bank Marketing, 7(6), 31-37. http://dx.doi.org/10.1108/0265232891013 2060

Fada, \& Wabekwa, B. (2012). People's Perception Towards Islamic Banking: A Field work study in Gombe Local Government Area, Nigeria. International Journal of Business, Humanities and Technology, 2(7), 21-131.

Faisal, M. A. A., \& Rahman, A. (n. d.). Awareness of Islamic bank in India An empirical study. Retrieved from https://www.academia.edu/5218913/AWARENESS_OF_ISLAMIC_BANKING_IN_INDIA-An_Empirical Study

Gait, A., \& Worthington, A. (2009). Attitudes, Perceptions and Motivations of Libyan Retail Consumers toward Islamic Methods of Finance. Paper presented to the Asian Finance Association 2009 International Conference.

Gerrard, P., \& Cunningham, J. B. (1997). Islamic Banking: A study in Singapore. International Journal of Bank Marketing, 15(6), 204-216. http://dx.doi.org/10.1108/02652329710184433

Haque, A., Osman, J., \& Ismail, A. Z. H. (2009). Factors influences selection of Islamic banking: A study on Malaysian customer performances. American Journal of Applied Sciences, 6(5), 922-928. http://dx.doi.org/ 10.3844/ajassp.2009.922.928

Haron, S., Ahmad, N., \& Planisek, S. L. (1994). Bank patronage factors of Muslim and non-Muslim customers. International Journal of Bank Marketing, 12(1), 32-40. http://dx.doi.org/10.1108/02652329410049599

Hidayat, S. E., \& Baward, N. A. K. (2012). Non-Muslim perception towards Islamic banking service in Saudi Arabia. Journal of US-China Public Administration, 9(6), 654-670.

Hin, C. W., Wei, C. C., Bohari, A. M., \& Adam, D. M. Z. A. (2011). Bank selection criteria and service quality of 
Islamic banking: A comparison between Muslim and non-Muslim students and its effect on student's satisfaction. Journal Economy, 14(3), 104-114.

Jamshidi, D., Hussin, N., \& Wan, H. L. (2013). The potential impact of demographic items on Islamic banking services acceptance and usage-a literature review. International journal of social science and humanities, $1(1), 34-39$.

Kasri, R. A., \& Kassim, S. H. (2009). Empirical determinants of saving in the Islamic banks: Evidence from Indonesia. JKAU: Islamic Economics, 22(2), 181-201.

Loo, M. (2010). Attitudes and Perceptions towards Islamic Banking among Muslims and non-Muslims in Malaysia: Implications for Marketing to Baby boomers and X-Generation. International Journal of Arts and Sciences, 3(13), 453-485.

Mamun, M. Z. (2011). Prospects and problems of Islamic banking from bank's perspective: A study of Bangladesh. Paper presented at the $8^{\text {th }}$ international conference on Islamic Economics and finance.

Marimuthu, M., Jing, C. W., Gie, L. P., Mun, L. P., \& Ping, T. Y. (2010). Islamic banking: Selection criteria and Implications. Global journal of Human Social Science, 10(4), 52-62.

Muniswamy, S., Soundararajan, G., \& Ramaswamy, R. (2013). Islamic Finance in India: A study on the perception of College Teachers in Chennai. Journal of Islamic Economics, Banking and Finance, 9(3), 131-147. http://dx.doi.org/10.12816/0001615

Nawi, F. A. M., Yazid, A. S., \& Mohammed, M. O. (2013). A Critical Literature Review for Islamic banks selection criteria in Malaysia. Canadian Center of Science and Education, 6(6), 143-151.

Okumus, S., \& Genc, E. G. (2013). Interest free banking in Turkey: A Study of customers Satisfaction and bank selection. European Scientific Journal, 9(16), 144-166.

Ramadan, Z. S. (2013). Jordanian criteria for Islamic banks selection. Evidence from the Jordanian banking sector. International Journal of Academic Research in Accounting, Finance and Management Sciences, 3(3), 139-145.

Ramdhony, D. (2013). Islamic Banking Awareness Attitudes and Bank Selection Criteria. International Journal of Humanities and Applied Sciences, 2(2), 29-35.

Rao, S., \& Sharma, R. K. (2010). Bank selection criteria employed by MBA students in Delhi: An Empirical Analysis. Journal of Business Studies Quarterly, 1(2), 56-69.

Rasheed, H., Aimin, W., \& Ahmad, A. (2012). An Evaluation of Bank Customer Satisfaction in Pakistan, Comparing Foreign and Islamic Banks. International Journal of Academic Research in Business and Social Sciences, 2(7), 177-184.

Rasheed, M., \& Kabir, M. H. (2009). Customer demographics affecting bank selection criteria, preference, and market segmentation: Study on domestic Islamic bank in Bangladesh. International Journal of Business and Management, 4(6), 131-146.

Saad, N. M. (2012). Comparative Analysis of Customer Satisfaction on Islamic and Conventional Banks in Malaysia. Asian Social Sciences, 8(1), 73-77.

Sheikh, R., \& Ahammad, M. F. (2013). The feasibility of establishing Islamic banks in the UK: The case of Nottingham. International Journal of Social Entrepreneurship and Innovation, 2(1), 67-82. http://dx.doi. org/10.1504/IJSEI.2013.052762

Yatoo, N. A., \& Muthu, S. S. (2013). Islamic Finance in India: An assessment of Idea and Awareness. International Journal of Islamic Banking and Finance, 3(2), 1-10. http://dx.doi.org/10.12816/0001425

\section{Copyrights}

Copyright for this article is retained by the author(s), with first publication rights granted to the journal.

This is an open-access article distributed under the terms and conditions of the Creative Commons Attribution license (http://creativecommons.org/licenses/by/3.0/). 